11. Shevchenko, S.G. Children with mental retardation: features of speech, writing, reading. Moscow: School press. 2014.

12. Skripkina, N.V. Psychological characteristics of readiness for school in older preschoolers with mental retardation. Modern psychology: materials of the V International. scientific. conf. Kazan: Buk, 2017, 86-91.

13. Sobotovich, E.F. Speech underdevelopment in children and ways to correct it. Moscow: Classic Style, 2013, 23-27.

14. Tarasun, V.V. Formation of the speech personality of a child with developmental disabilities. Scientific Bulletin of Luhansk National University. T. Shevchenko, 2013, 165-173.

15. Ulyenkova, U. V. Formation of the general learning ability of six-yearold children. Moscow. 1990.

16. Vlasova, T.A., Pevzner M.S. To the teacher about children with developmental disabilities. Moscow: Sfera shopping center. 1973.

DOI https://doi.org/10.30525/978-9934-26-146-6-41

\title{
СУЧАСНІ ПОГЛЯДИ НА ПРОБЛЕМУ АЛАЛІї
}

\section{Мурліна Ю. Р.}

студентка спечіальності «Спечіальна освіта»

Комунальний заклад «Харківська гуманітарно-педагогічна академія»

Харківської обласної ради

\section{Птуха А. Р.}

студентка спеціальності «Спеціальна освіта»

Комунальний заклад «Харківська гуманітарно-педагогічна академія»

Харківської обласної ради

Гончар Г. Д.

викладач кафедри корекційної освіти та спеціальної психології

Комунальний заклад «Харківська гуманітарно-педагогічна академія»

Харківської обласної ради

м. Харків, Україна

Сучасна логопедія потужно збагачується міждисциплінарними знаннями 3 нейропсихології, психолінгвістики, неврології, психіатрії. Цей процес актуалізує дискусійні погляди на мовленнєві порушення, у тому числі - на алалію.

У різні часові відрізки алалію досліджували Р. Бєлова-Давид, Л. Волкова, П. Гуровець, Г. Гуцман, В. Ковшиков, Р. Коен, А. Кусмауль, 
Р. Левіна, А. Лібман, I. Мартиненко, О. Мастюкова, С. Соботович, Н. Трауготт, М. Хватцев, М. Шеремет та інші.

Мета цієї статті: виокремити напрямки сучасної професійної дискусії щодо концепту «алалія».

На нашу думку, такими напрямками $є$ проблеми термінології, питання поділу алалії на різні форми, перегляду місця алалії у наявних класифікаціях мовленнєвих порушень (вітчизняних та закордонних), проблема патогенезу алалії, локалізації порушень, диференціації від інших порушень мовленнєвого розвитку.

Алалія - це відсутність або недорозвиток мовлення, спричинений органічним ураження мовленнєвих зон кори головного мозку внутрішньоутробно чи у ранньому віці. Поряд із терміном «алалія» існує термін «дисфазія» (від «дис»- порушення, «фазіс»- мовлення) i часто використовується як синонім алалії. Різниці між двома термінами немає; плутанина, яка виникає при оперуванні ними, пов'язана 3 використанням спеціалістами різних класифікацій порушень [3, с. 40].

Питання форм алалії та місця цього мовленнєвого порушення у існуючих класифікаціях ще не вирішено остаточно. За всю історію вивчення алалії існувало багато класифікацій цього порушення, адже на кожному етапі проводилися нові дослідження, які змінювали уявлення науковців про дану форму мовленнєвого порушення. Але класифікації таких вчених, як А. Лібман (три форми алалії, яку він позначає терміном глухонімота: моторна, сенсорна, сенсомоторна), Р. Левіна (форми 3 неповноцінним слуховим сприйманням, порушенням зорового сприймання, порушенням психічної активності), В. Орфінська (10 форм алалії за механізмами виникнення, патогенезом та характером мовних порушень), В. Ковшиков (імпресивні та експресивні алалії), $€$. Соботович (дві форми алалії: 3 порушенням синтаграматичних та парадигматичних систем мовлення) $€$ дещо застарілими та мають розбіжності [3, с. 40].

Нині існують дві найпоширеніші класифікації мовленнєвих порушень. Перша - клініко-педагогічна, за якою алалія належить до групи порушень структурно-семантичного оформлення вислову. Друга - психолого-педагогічна, за якою алалія входить до групи порушень засобів спілкування і може бути співвіднесена із ЗНМ.

3 плином часу після багаторічних досліджень питання патогенезу алалії було виявлено та доведено необхідність подальшого вивчення проблеми за допомогою таких підходів, як системний, комплексний, міждисциплінарний. На сьогодні вивчені ще не всі аспекти проблеми, що не у всіх випадках дозволяє точно обрати методи корекції 
порушення, а це в свою чергу знижує ефективність логопедичної допомоги.

Сучасники вивчають алалію 3 фізіологічних, клінічних, психологічних, лінгвістичних та психолінгвістичних позицій. У переважній більшості літератури алалія описується як порушення мовлення, спричинене органічним ураження кори головного мозку.

Саме питання причини виникнення алалії останнім часом набуло у науковому світі дискусійного значення. Традиційні погляди на виникнення алалії через ураження зони Брока відкидає ряд науковців. Т. Візель (2019) доводить, що у сучасній літературі не представлені випадки, що анатомічно підтвердили б під час розтину ураження мовленнєвих зон. Результати досліджень нейрофізіологічних особливостей функціонування мозку у дітей з алалією відзначаються неоднорідністю, проте більшість авторів повідомляють, що вони не отримали переконливих даних щодо наявності у дітей 3 алалією ураження області, що традиційно позначається як зона Брока [1, с. 5].

Експериментальні дані Т. Візель та А. Скального (2008) свідчать на користь припущення, що причиною алалії можуть бути збої мозкової діяльності на нейронному рівні (демієлінізація) або порушення мікроелементного складу волокон. Отже, немовленнєвість не $\epsilon$ наслідком ураження мозкової кори, а обумовлена відсутністю зв'язків між зонами мозку, які беруть участь у формуванні мовлення. На цьому тлі важливого значення набуває збереження та відновлення провідників в мозку [2, с. 160$]$.

У своїй праці «Проблеми мовного розвитку дітей: у пошуках» Т. Візель підсумовує, що відсутність осередків ураження і наявність алалії пояснюється тим, що непошкоджені області мозку залишаються функціонально роз'єднаними і нездатними здійснювати необхідні для мовлення операції. При цьому наявність осередків ураження за відсутності алалії пояснюється тим, що уражені ділянки мозкової тканини (за умови збереження провідників) можуть замінюватися іншими, інтактними, які отримують замісну спеціалізацію. Автор зазначає, що це підтверджує гіпотези про принципово важливу особливість дитячого мозку - пластичність $[1$, с. 5].

Схожу версію викладають M. Berthier, G. Davila, M. Torres-Prioris, I. Moreno-Torres. Вони вказують, що особи з порушеннями мовлення зазвичай мають більш слабку церебральну латерізацію. Алалії та афазії через односторонні ураження домінантної півкулі рідко призводять до загальних порушень, бо адаптивна нейронна пластичність сприяє видужанню. I навпаки, наявність загальних порушень як правило вказує на двосторонні аномалії мозку. Більшість порушень мовлення не 
пов'язані з грубими структурними ураженнями мозку, але затримка мовлення може бути дещо пов'язана з одностороніми, двосторонніми чи дифузними кірковими аномаліями розвитку; при цьому характеристика затримки мовлення і ії зв'язок з грубими порушеннями розвитку мозку не визначені досить чітко [4].

Тож у питанні патогенезу алалії науковці розділилися на два табори: традиційний, прихильники якого вважають причиною ураження кори головного мозку, та новаторський, прихильники якого називають причиною відсутність зв'язків між зонами головного мозку, що відповідають за мовлення.

Сучасні науковці вважають актуальною проблемою вивчення алалії не лише питання виникнення, а й диференціації від інших порушень психофізичного розвитку: сенсорних (глухота та туговухість), інтелектуальних (розумова відсталість, затримка психічного розвитку), аутизму.

В. Тищенко вказує на те, що диференційні ознаки форм алалії можна виявити в мовленні дитини лише після трьох років за наявності елементарного мовлення. Але самі ознаки, що можуть вказувати на алалію, помічають ще в ранньому віці. Дослідник пише, що алалію слід віддиференціювати від дизартрії. Моторна алалія, як і дизартрія, зокрема, анартрія, можуть викликати грубий недорозвиток мовлення в фонетикофонематичній ланці, що тягне за собою недорозвиток лексикограматичних складників мовлення. За таких умов, стан мовленнєвої функції дитини з моторною алалією та складною дизартрією може бути схожим. Також спеціаліст може сплутати алалію із затримкою мовленнсвого розвитку та затримкою психічного розвитку. Віддиференціювати можно лише за рядом ознак: діти з алалією мають загальні моторні утруднення, сенсо-акустичний синдром, амнестичний синдром, оптико-просторові порушення тощо. Так само при диференціації алалії та туговухості або глухоти перш за все спираються на дані лікаряотоларинголога та ряд ознак: зазвичай діти 3 алалією мають дзвінкий голос, для них характерні недостатній зв'язок образу із назвою, нестійка слухова реакція, небажання говорити тощо [5, с. 246-247].

Останнім часом питання алалії викликає в науковому світі дискусії, починаючи від трактування терміну і закінчуючи складними питаннями класифікації, патогенезу, диференціації від інших порушень розвитку. Найбільше суперечок викликає питання виникнення алалії як порушення психофізичного розвитку. Погляди на патогенез алалії розділилися. Залишилися прихильники теорії, що ураження мовних зон кори головного мозку спричиняє алалію, але також з'явилися дослідники-новатори, які вважають причиною виникнення алалії 
порушення зв'язків між зонами кори головного мозку, що відповідають за мовлення. Досі досить гостро стоїть проблема диференціації алалії від інших порушень. Незважаючи на те, що вже існують досить точні праці з теми, спеціалісти все ще можуть помилятися, коли кордони між двома порушення психофізичного розвитку розмиті.

\section{Література:}

1. Визель Т.Г. Проблемы речового развития детей: в поисках. Московский институт психоанализа : Когито-Центр, 2019. 240 с.

2. Визель Т.Г., Клевцова С.В. Жёсткие и гибкие звенья развития речи (нейропсихологический и нейролингвистический аспекты). Специиальное образование. 2020. № 4. С. 157-170.

3. Зелінська-Любченко К. О. Історичний аспект вивчення проблеми локалізації уражень мовленнєвої системи при моторній алалії. Науковий часопис. Корекиійна педагогіка. 2016. № 31. С. 40-43.

4. Marcelo L. Berthier, Guadalupe Davila, Maria Jose Torres-Prioris, Ignacio Moreno-Torres та ін. Developmental Dynamic Dysphasia: Are Bilateral Brain Abnormalities a Signature of Inefficient Neural Plasticity? Frontiers in Human Neuroscience. 2020. № 73. URL: https://doi.org/10.3389/fnhum.2020.00073

5. Тищенко В.В. Диференційна діагностика алалії та інших порушень психофізичного розвитку. Науковий часопис. Актуальні проблеми логопедіï. 2011. № 18. С. 246-249.

DOI https://doi.org/10.30525/978-9934-26-146-6-42

\section{ЗАСВОСННЯ ГРАМАТИЧНОЇ КАТЕГОРІЇ ВІДМІНКА ШКОЛЯРАМИ ІЗ ТЯЖКИМИ ПОРУШЕННЯМИ МОВЛЕННЯ}

\section{Рібцун Ю. В.}

кандидат педагогічних наук, старший науковий співробітник, старший науковий співробітник відділу логопедії Інститут спеціальної педагогіки і психології імені Миколи Ярмаченка Начіональної академії педагогічних наук України м. Київ, Україна

Вектор удосконалення змісту сучасної освіти, у т. ч. й спеціальної, чітко спрямований на формування у школярів компетентностей, потрібних їм для ефективної подальшої самореалізації в суспільстві. 158 